\title{
Parkinson Hastalığı Olan Bir Olguda Optik Atrofi
}

\section{Optic Atrophy in a Patient with Parkinson's Disease}

Zeynep Dadacı ${ }^{1}$,

Fatma Doğanay²,

Nurşen Öncel Acır ${ }^{3}$,

Cengiz Kadıyoran ${ }^{4}$

${ }^{1}$ Medova Hastanesi, Konya, Türkiye

${ }^{2}$ Akademi Konya Hastanesi, Konya, Türkiye

${ }^{3}$ Dünya Göz Hastanesi, Konya, Türkiye

${ }^{4}$ Necmettin Erbakan Üniversitesi Tıp

Fakültesi, Radyoloji Anabilim Dalı, Konya,

Türkiye

Geliş Tarihi/Received: 19 Şubat 2018

Kabul Tarihi/Accepted: 24 Mart 2018

Yazışma Adresi: Zeynep Dadacı,

Medova Hastanesi, Konya, Türkiye

e-posta: zdadaci@hotmail.com

ORCID

Zeynep Dadacı

https://orcid.org/0000-0002-0246-4066

\begin{abstract}
Öz
Parkinson hastalığı $(\mathrm{PH})$ temel olarak beyin bazal gangliyonlarındaki dopaminerjik nöronların kaybına yol açan ilerleyici nörodejeneratif bir bozukluktur. Hastalığın temel özellikleri tremor, bradikinezi ve rijiditedir. Parkinson hastalığının birçok motor-dışı belirtilerinden biri de görme sistemi tutulumudur. Parkinson hastalığında retina sinir lifi tabakasında incelme gelişmektedir. Çalışmamızda, makula ve retina sinir lifi tabakası kalınlığında incelmenin yanı sıra bilateral optik atrofisi olan Parkinson hastası bir olguyu tarif ettik.

Anahtar Kelimeler: Parkinson hastalığı, optik atrofi, retina sinir lifi tabakası

\section{Abstract}

Parkinson's disease (PD) is a progressive neurodegenerative disorder that leads to a selective loss of dopaminergic neurons in the basal ganglia of the brain. The main characteristics of the disease are tremor, bradykinesia and rigidity. There are also several non-motor manifestations of PD, one of which is visual system involvement. There is a decrease in retinal nerve fiber layer thickness in PD. In our study, we described bilateral optic atrophy along with a decrease in macular and retinal nerve fiber layer thickness in a patient with PD.

Keywords: Parkinson's disease, optic atrophy, retinal nerve fiber layer
\end{abstract}

\section{GíRiş}

Parkinson hastalığı $(\mathrm{PH})$ temel olarak beyin bazal gangliyonlarındaki dopaminerjik nöronların kaybına yol açan ilerleyici nörodejeneratif bir bozukluktur. Altmış yaş üzeri toplumda yaklaşık olarak \%1 oranında bildirilen $\mathrm{PH}$ en sık görülen nörodejeneratif hastalıklardan biridir $(1,2)$. Hastalığın temel özellikleri tremor, bradikinezi ve rijiditedir. Daha önceleri motor sistem bozukluğu olarak değerlendirilen PH'nın son zamanlarda nöropsikiyatrik ve diğer motor-dışı belirtiler de dahil olmak üzere geniş aralıkta klinik özellikleri içeren kompleks bir durum olduğu kabul edilmektedir (1). Görme hastalıkta etkilenen motor-dışı sistemlerden biridir. Son yıllarda yapılan çalışmalarda PH'nda retina sinir lifi tabakası kalınlığının azaldığı gösterilmiştir (3).

Optik siniri retina gangliyon hücrelerinden orijin alan yaklaşık 1.2 milyon akson oluşturmaktadır. Optik siniri oluşturan aksonlar hasara uğradıkları zaman tekrar rejenere olmazlar. Retinogenikülat yolaktaki aksonların dejenerasyonuna yol açan her türlü hastalık sürecinin morfolojik olarak son ortak noktası optik atrofidir. Klinik olarak optik atrofi değişken derecelerde görsel disfonksiyonla birlikte optik diskin renk ve yapısındaki değişikliklerle karakterizedir (4).

Çalışmamızda optik atrofiye neden olabilecek herhangi bir başka hastalık ve risk faktörü olmayan ve bilateral optik atrofisi olan Parkinson hastası bir olguyu tarif ettik. Her ne kadar PH'nda çeşitli görsel bozukluklar ve retina sinir lifi tabakasında incelme daha önce rapor edilmiş olsa da doğrudan PH'na bağlı olarak bildirilen optik atrofi olgusuna literatür araştırmamızda rastlamadık.

\section{OLGU}

73 yaşında erkek hasta bulanık görme şikayeti ile polikliniğimize başvurdu. Oftalmolojik muayenesinde düzeltilmiş en iyi uzak görme keskinliği sağ gözde 0.4, sol gözde 0.6 (Snellen Eşeli) idi. Işık refleksi bilateral hiporeaktifti. Ishiara testi ile yapılan renkli

Atıf yapmak için: Dadacı Z, Doğanay F, Acır NÖ, Kadıyoran C. Parkinson Hastalığı Olan Bir Olguda Optik Atrofi. Selcuk Med J 2019;35(4): 264-266 
görme değerlendirmesi her iki gözde bozuk izlendi. Biyomikroskopik incelemesinde bilateral kornükleer kataraktı tesbit edilen hastanın dilatasyonlu göz dibi muayenesinde her iki optik diskte belirgin yaygın solukluk izlendi. Aplanasyon tonometrisi ile ölçülen göz içi basınçları sağ gözde 13, sol gözde $12 \mathrm{mmHg}$ idi. Santral kornea kalınlıkları sağ gözde 548, sol gözde 550 mikron olarak ölçüldü. 1994 yılından beri olan $\mathrm{PH}$ dışında herhangi bir sistemik hastalık öyküsü, geçirilmiş ameliyat, kaza, sigara ve alkol kullanımı ve malnütrisyon bulunmamaktaydı. Kraniyal görüntülemede kafa içi veya orbital kitle izlenmedi. Ropinirol 1x1, Rasajilin 1x1, 100 mg Levodopa, 25 mg Karbidopa ve 200 mg Entakapon 3x1 dışında sürekli kullandığı herhangi bir sistemik ilaç yoktu. Çekilen optik kohorens tomografisinde retina sinir lifi tabakası ve makula kalınlıklarında belirgin azalma mevcuttu (Şekil 1).

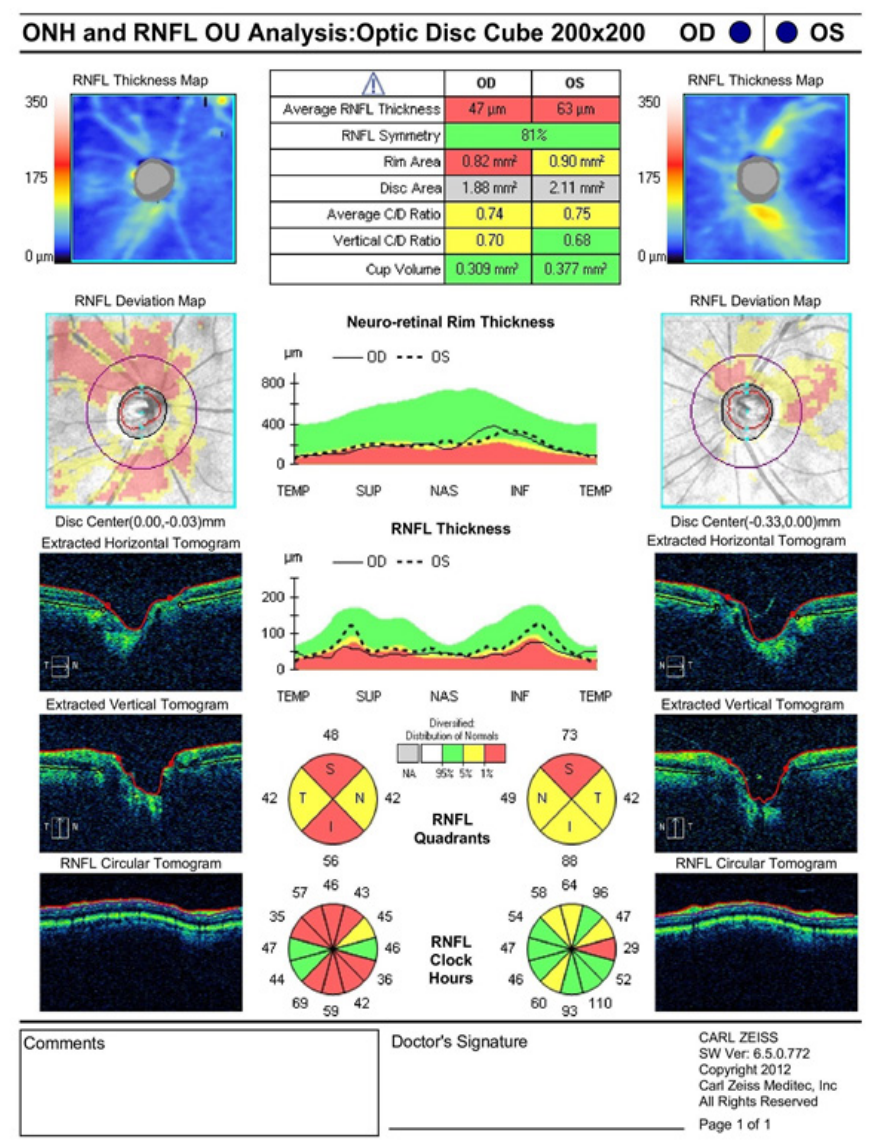

Şekil 1. Optik kohorens görüntülemede retina sinir lifi tabakasında incelme izleniyor.

\section{TARTIŞMA}

Parkinson hastalığında substantia nigradaki pigmente nöronların kaybının yanı sıra, retinadaki dopaminerjik amakrin hücreler, retina gangliyon hücreleri ve lateral genikülat cisim ve vizüel korteks gibi alanlarda da nöron kaybı görülmektedir (5). Retina gangliyon hücrelerindeki bu azalma sonucu gelişen retina ve retina sinir lifi tabakasında incelme yüksek çözünürlükte görüntü alma imkanı veren optik kohorens tomografi yöntemiyle hassas bir şekilde tespit edilebilmektedir (6,7). Satue et al. (6). $100 \mathrm{PH}$ olgu ve 100 sağlıklı bireyi karşılaştırdıkları çalışmada Parkinson hastalarında belirgin oranda retina sinir lifi kaybı ve retinal incelme bildirmişlerdir. Biz de olgumuzda optik kohorens tomografi görüntüleme ile retina sinir lifi ve makula kalınlıklarında belirgin incelme tespit ettik.

Konjenital veya edinsel birçok farklı neden optik atrofiye yol açabilmektedir. İskemik durumlar, metabolik bozukluklar, demiyelinizan hastalıklar, optik sinire bası veya optik sinirin traksiyonu, inflamasyon ve travma gibi nedenlerin yanı sıra yaygın koryoretinal atrofiye yol açan olan bazı göz hastalıklarına sekonder olarak da optik atrofi gelişebilir (4). Mitokondriyal ve nörodejeneratif hastalıklarda da optik atrofi gelişimi sıklıkla görülmektedir (8). Konjenital optik atrofi nedeni olan Leber'in kalıtsal optik nöropatisi mitokondrial DNA'daki mutasyon sonucu gelişmekte ve maternal geçiş göstermektedir (9). Edinsel olarak vitamin eksiklikleri, toksik maruziyetler, alkol ve sigara kullanımı ve bazı ilaçların kullanımı gibi çeşitli durumlar da mitokondriyal disfonksiyona yol açarak optik atrofiye neden olabilmektedir (10).

Parkinson hastalığı ile ilişkili bazı genetik faktörler bildirilmiş olmasına rağmen hastaların büyük bir bölümünde PH'nın nedeni bilinmemektedir $(1,2)$. Mitokondriyal disfonksiyonun PH'nda erken ve tetikleyici rol oynadığı ileri sürülmüştür (11). Ayrıca PH'nda gözlenen retina sinir lifi kaybı paterninin Leber'in kalıtsal optik nöropatisi gibi kalıtsal mitokondriyel optik nöropatilerle benzeştiği bildirilmiştir (12). Bizim olgumuzda PH ve bilateral optik atrofinin birlikte bulunması her iki hastalığında patogenezinde rol oynadığı ileri sürülen mitokondriyal disfonksiyona bağlı olabilir.

Çıkar Çatışması: Çalışmada herhangi bir çıkar çatışması yoktur.

Finansal Çıkar Çatışması: Çalışmada herhangi bir finansal çıkar çatışması yoktur.

Yazışma Adresi: Zeynep Dadacı, Havzan Mah. Yeni Elektrik 
Santral Cad. Altınbaşak Konakları 4C/4 Konya, Türkiye Tel: +905337269070

e-mail: zdadaci@hotmail.com

\section{KAYNAKLAR}

1. Langston JW. The Parkinson's complex: Parkinsonism is just the tip of the iceberg. Ann Neurol 2006;59(4):591-6.

2. Agim ZS, Cannon JR. Dietary factors in the etiology of Parkinson's disease. BioMed Res Int 2015;2015:672838.

3. Bodis-Wollner I. Retinopathy in Parkinson disease. J Neural Transm Vienna Austria 1996 2009;116(11):1493-501.

4. Albert DM, Jakobeic FA. Optic atrophy. In: Principles and Practice of Ophthalmology. 2nd ed. Philadelphia: WB Saunders; 2000:4108-13.

5. Archibald NK, Clarke MP, Mosimann UP, et al. The retina in Parkinson's disease. Brain J Neurol 2009;132(Pt 5):1128-45.

6. Satue M, Garcia-Martin E, Fuertes I, et al. Use of Fourierdomain OCT to detect retinal nerve fiber layer degeneration in Parkinson's disease patients. Eye Lond Engl 2013;27(4):50714.
7. Rohani M, Langroodi AS, Ghourchian S, et al. Retinal nerve changes in patients with tremor dominant and akinetic rigid Parkinson's disease. Neurol Sci 2013;34(5):689-93.

8. Maresca A, la Morgia C, Caporali L, et al. The optic nerve: A "mito-window" on mitochondrial neurodegeneration. Mol Cell Neurosci 2013;55:62-76.

9. Wallace DC, Singh G, Lott MT, et al. Mitochondrial DNA mutation associated with Leber's hereditary optic neuropathy. Science 1988;242(4884):1427-30.

10. Carelli V, Ross-Cisneros FN, Sadun AA. Mitochondrial dysfunction as a cause of optic neuropathies. Prog Retin Eye Res 2004;23(1):53-89.

11. Schulz JB, Beal MF. Mitochondrial dysfunction in movement disorders. Curr Opin Neurol 1994;7(4):333-9.

12. La Morgia C, Barboni P, Rizzo G, et al. Loss of temporal retinal nerve fibers in Parkinson disease: A mitochondrial pattern? Eur J Neurol Off J Eur Fed Neurol Soc 2013;20(1):198-201. 